\title{
GENETICALLY ENGINEERED GENES: WHEN HAVE WE GONE TOO FAR?
}

\author{
JULIA ODENDAAL* \\ clo Biology Dept., Mount Saint Vincent University, Halifax, NS
}

DNA is the code for what we call GENES, genes are the holder of all our personality traits like our hair colour, eye colour, how tall or short we are, etc. We have of thousands of genes. David Suzuki has talked a lot about genes, and how some genes carry illnesses (Suzuki, 2019), like different forms of cancer, cystic fibrosis, sickle cell anemia and many more illnesses that doctors struggle to find cures for. Now scientists think they have found a way to eliminate these illnesses forever. They have developed a strategy called CRISPR; it is a scientific method to place genes back into cells. This basically means they can extract one bad gene (a gene that carries an illness or disease), and then modify it and put it back. Like if you were to need a new battery for your phone, first they open it up, find the problem, remove the problem, replace with a new "battery" and close the phone back up and it's ready to go. Problem solved, easy as that. CRISPR is the remove, fix and replace method scientists have discovered to help cure that "bad" gene that makes faulty proteins that is killing hundreds of thousands of people every year.

Not only have scientists discovered that they can remove, fix and replace parts of genes in living humans, they have also discovered that they can use CRISPR to potentially create what we call "designer babies". Designer Babies are basically totally customized humans. You could pick everything from hair and eye colour to personality traits like being artistic or athletic. The real question is should scientists be doing these things, just because they could with a little more technology and understanding how genes work. Is there really a need for totally customized babies. CRISPR can be used to edit the genes in body cells, that can ultimately be used for curing illnesses and diseases. Or it can be used to edit genes in germ line cells, to prevent diseases. Germ cell editing can be inherited, so if they are changed a gene, then the edited gene will be passed along to the next

\footnotetext{
* Author to whom correspondence should be addressed:

Tamara.Franz-Odendaal@msvu.ca
} 
generation. The problem is that we don't know what we don't know. There could be many errors but at this time we have no idea what they are and when they will appear.

There is a group of people going by the name biohackers! These people are attempting to engineer their own genes in the comfort of their own homes, which can be extremely dangerous.

What are we willing to allow and what are we not? When have scientists gone too far? In fact, the US FBI thinks of CRISPR as a weapon of possible mass destruction. Canada has a law against using CRISPR for customizing living things (which includes pets, humans, other animals or plants). Canada was smart to make strict rules before they were even needed. Many people including qualified scientists and doctors are attempting to bend the laws in order to invent and create the future generation of designer babies. Although I'm not quite sure we're ready for this, it's happening whether we like it or not.

\section{REFERENCES}

Doudna, J.A. \& Sternberg, S.H. (2017). A crack in creation: Gene editing and the unthinkable power to control evolution. Houghton Mifflin Harcourt, New York.

Lander, E.S., Baylis, F., Zhang, F., Charpentier, E., Berg, P., Bourgain, C., Friedrich, B., Joung, J.K., Li, J., Liu, D., Naldini, L., Nie, J-B., Qiu, R., Schoene-Seifert, B., Shao, F., Terry, S., Wei, W., \& Winnacker, E. (2019). Adopt a moratorium on heritable genome editing". Nature 567: 165-168.

Suzuki, D. (n.d.). Human gene-editing is already here - are we ready? The Nature of Things. https://youtube/EoegNIT9WeE. 